Article

\title{
Insects and the Kafkaesque: Insectuous Re-Writings in Visual and Audio-Visual Media
}

\author{
Damianos Grammatikopoulos
}

German Language and Literature Program, School of Arts and Sciences, New Brunswick, NJ 08901, USA; damiangr@scarletmail.rutgers.edu

Received: 16 June 2017; Accepted: 13 September 2017; Published: 16 September 2017

\begin{abstract}
In this article, I examine techniques at work in visual and audio-visual media that deal with the creative imitation of central Kafkan themes, particularly those related to hybrid insects and bodily deformity. In addition, the opening section of my study offers a detailed and thorough discussion of the concept of the "Kafkaesque", and an attempt will be made to circumscribe its signifying limits. The main objective of the study is to explore the relationship between Kafka's texts and the works of contemporary cartoonists, illustrators (Charles Burns), and filmmakers (David Cronenberg) and identify themes and motifs that they have in common. My approach is informed by transtextual practices and source studies, and I draw systematically on Gerard Genette's Palimpsests and Harold Bloom's The Anxiety of Influence.
\end{abstract}

Keywords: Kafka studies; adaptation studies; narratology; intertextuality; intermediality; mimesis; emulation; imitation; repetition; parody

\section{An Introduction to the Kafkaesque}

unlike a proper name, which moves from the interior of a discourse to the real person outside who produced it, the name of the author remains at the contours of texts-separating one from the other, defining their form, and characterizing their mode of existence.

(Foucault 1980, p. 123)

In his seminal essay What Is an Author (1969), Michel Foucault argues that the main function of an author's name, as opposed to a proper name, is to delineate the confines of an author's oeuvre and draw a line between her texts and those composed by other writers. John Searle on the other hand, in his treatise on Proper Names (1918) and their linguistic properties, is more concerned with the referential function of both proper and authorial names. Names, as he maintains, have no meaning per se and do not act as definite descriptions. Their main purpose is not to describe but to refer to an individual who is the bearer of that name. That same individual, however, is marked by a set of characteristics that the proper name inevitably evokes when it is pronounced or when it appears in writing. As Searle argues: "proper names do not normally assert or specify any characteristics, their referring uses nonetheless presuppose that the object to which they purport to refer has certain characteristics" (Searle [1958] 1970, pp. 170-71). Names themselves are meaningless, yet they tend to assimilate the traits and distinctive features of the person to whom they refer. "They function not as descriptions, but as pegs on which to hang descriptions" (Searle [1958] 1970, p. 172). Michel Foucault on the other hand famously posits a difference between a proper and an author's name by calling attention to the intrinsic relationship between the name of an author and her corpus. For Foucault, the name of a writer acts as a border patrol agent of sorts, guarding the invisible boundaries of texts written by different authors and preventing "intruders" to enter the textual territory they safeguard. The aim 
of an author's name for Foucault is the protection of private property. Without the contribution of a name to police those margins, the classification of texts would not be possible:

These differences indicate that an author's name is not simply an element of speech (as a subject, a complement, or an element that could be replaced by a pronoun or other parts of speech). Its presence is functional in that it serves as a means of classification. A name can group together a number of texts and thus differentiate them from others. A name also establishes different forms of relationships among texts.

(Foucault 1980, p. 123)

What Foucault alludes to here are the possessive qualities of names. By adding an apostrophe and the letter " $\mathrm{s}$ " at the end of a name, we no longer refer to an individual but to her possessions, which in the case of an author include her writings. The phrases "Lacan's texts" and "Lacan's house" no longer refer to the author Lacan but to certain objects that belong or belonged to him. By slightly transforming an author's name, we perform an act that affects its reference. Similarly, when certain suffixes are added at the end of a name, the name itself becomes an adjective. By attaching the suffix "-ian", for instance, to the stem of an author's name (Freud-ian, Lacan-ian, Kafk-ian and Kafka-ian), the newly formed derivative does indeed define the borders of an author's oeuvre, as Foucault claims, but it does so only when accompanied by certain nouns (text, corpus, oeuvre): "the Freudian corpus", "the Lacanian oeuvre" etc. Furthermore, the same suffix in conjunction with an author's name conveys a distinctive quality at play in the texts of an author, which can be used as a means of comparison: "the Orwellian surveillance state". The suffix "-ean" operates in a similar manner, as in: "Derrid-ean" (the Derridean oeuvre, a Derridean notion). ${ }^{1}$

Words ending in "-esque" represent a further class of suffixes capable of turning a name into an adjective. The online Merriam-Webster definition of the same suffix reads as follows: "in the manner or style of" (Online Merriam-Webster 2017a). As opposed to the suffixes discussed above, adjectives ending in "-esque", the stem of which contains a name, are not suitable in delineating an author's oeuvre (the phrase "the Kafkaesque corpus" is rather misleading). Their function is restricted to the denotation of properties that are at play in works composed by an author. Many adjectives composed of an author's name and the suffix "-esque" have found entrance into the English language, as in Dantesque, Chaplinesque, Dylanesque, and even Jordanesque (from Michael Jordan), yet the most well-know of all of them is arguably the derivative Kafkaesque which Robert Crumb and David Zane Mairowitz labeled The Adjective: "At best, an identifiable mood pervades his work, mysterious and difficult to pinpoint. Which has allowed the 'pork-butchers' of modern culture to turn him into an Adjective" (Crumb and Mairowitz 2010, p. 5).

However, what does Kafkaesque really mean and what qualities in Franz Kafka's work does it transmit? What is the relationship between Kafka's name and its adjectival form? The online Merriam-Webster dictionary provides a definition that seems to comprise the basic meaning of the word in everyday language: "of, relating to, or suggestive of Franz Kafka or his writings; especially: having a nightmarishly complex, bizarre, or illogical quality: Kafkaesque bureaucratic delays" (Online Merriam-Webster 2017b). Most English and German dictionaries define the word along similar lines, yet some critics and artists have offered more elaborate views on the subject. The critic Rainer Nägele, for example, delimits the concept ex negativo by outlining what it excludes and claims that the Kafkaesque is never "uncanny" (Nägele 2006, p. 21). His study counters Tzvetan Todorov's assertion that "Kafka's narratives relate both to the marvelous and to the uncanny" (Todorov 1973, p. 172) and he sets out to prove that the Kafkaesque does not include any "uncanny" notions. Frederick Karl provides another definition of the Kafkaesque in his critical Kafka biography Representative Man (Karl 1991), delineating the concept as follows: "For Kafkaesque at its most meaningful and exalted

1 The word "Kafk-ean" is rather uncommon but not entirely absent in critical essays: “The Kafkean Law" (Žižek 2008, p. 87). 
denotes a world that has its own rules, its own guidelines, its own forms of behavior that cannot be amenable to human will" (Karl 1991, p. 757). Kafkaesque, as Karl goes on to argue, "has become the representative adjective of our times". (Karl 1991, p. 757). Yet the Adjective, as Crumb and Mairowitz argue, implies much more:

Because his novels The Trial and The Castle deal with the inaccessibility of higher authority, "Kafkaesque" has come to be associated with the faceless bureaucratic infrastructure which the highly efficient Austro-Hungarian Empire bequeathed the Western world. In any case, it is an adjective that takes on almost mythic proportions in our time, irrevocably tied to fantasies of doom and gloom, ignoring the intricate Jewish Joke that weaves itself through the bulk of Kafka's work.

(Crumb and Mairowitz 2010, p. 5)

Crumb and Mairowitz foreground the multi-faceted dimension of the term as an underdetermined signifier that struggles to express, at least at the vernacular level, the convoluted and ineffable overall quality of Kafka's oeuvre. Many critics and Kafka-ists (another interesting suffix in conjunction with an author's name), however, expose the multivalence of the concept that can be deployed to designate a plethora of meanings. The following definitions of the Kafkaesque taken from the recently published selection of essays entitled Mediamorphosis: Kafka and the Moving Image (2016) highlight the wide array of meanings that critics attribute to the term. According to Martin Brady and Helen Hughes, Kafkaesque characterizes more than just dream-like qualities:

On the one hand there is the strongly visual use of language-metaphor, analogy, a meticulous naturalism in the description of architectural space and landscape, for example - and on the other the restricted viewpoint of the protagonists. Together these make for the disconcerting world-view generally labelled "Kafkaesque."

(Brady and Hughes 2016, p. 182)

Shai Biderman relates the term to linguistic properties: "Kafka's style of writing is indicative to his control over the linguistic medium, and, as such, is an archetypical condition of the Kafkaesque" (Biderman 2016, p. 204). The combination of humor and horror falls into the same category as well, as Iris Bruce suggests: "What is thoroughly Kafkaesque in these scenes is the combination of humor and horror in Cronenberg's exploration of deeply rooted anxieties, which include the fear of losing control over one's body, of succumbing to irrational animalistic impulses, of being entirely at their mercy, which we see in Gregor as well" (Bruce 2016, p. 216). What becomes evident here is the fact that the Kafkaesque has no fixed meaning as an adjective that defines the essential quality of Kafka's texts. It means whatever an interpreter associates with Kafka's stories. It comes as no surprise, then, that many critics avoid the term because of its ambiguousness and ubiquity, and prefer the more neutral "Kafkaian", "Kafkian", and "Kafkan" (an abbreviated form of the "-ian" adjective ending that appears multiple times in the aforementioned Mediamorphosis selection of essays) when referring to distinctive properties of Kafka's texts, whatever those might be, all of which seem to act as synonyms of the Kafkaesque.

It is significant to note that adjectives ending in "-esque", as evidenced by the case of the Kafkaesque, conform to Searle's theory of proper names. Their function is not to define or describe. Rather, they serve as "pegs on which to hang descriptions. Thus, the looseness of the criteria for proper names is a necessary condition for isolating the referring function from the describing function of language" (Searle [1958] 1970, p. 172). The impossibility of pinning down the meaning of the Kafkaesque, its "looseness", resembles the properties of proper names whose aim is to refer (in this case to the author and/or her work) and not to describe (the same author and/or her work). The Kafkaesque does not act as a conventional adjective but rather as a name. It refers to Kafka's work, just like his name does, but it is the reader who assigns meanings and "hangs descriptions" to its derivatives. In the vernacular, on the other hand, the Kafkaesque appears to have broken the chains 
that bound it to its origin, Kafka's proper name and his texts. In German, it is known as "kafkaesk" and it was initially employed, as Thomas Anz states, in instances relating to imitations of Kafka's texts and distinctive properties of his stories. Yet "kafkaesk" became (in)famous once it entered the vernacular, in its social application, and since then, as Anz remarks, it is only remotely connected to Kafka's literary work (Anz 1992, p. 14). Owing to that phenomenon, its meaning appears to be more stable among individuals who have not read Kafka's texts but still use the word to express "a nightmarishly complex, bizarre, or illogical quality".

Now that a theoretical frame for the concept of the Kafkaesque has been established, it is time to explore some of its (mimetic) manifestations in cartoons, comics, and films in which a central visual quality of the Kafkaesque comes to the fore. In the following sections, I focus on narratives in which the Kafkaesque is linked to hybrid insects and to a lesser extent to the theme of bodily deformity. My analysis in not concerned with graphic or cinematic adaptations of Kafka's text, but with stories that indirectly draw on Kafka's visual vocabulary. I argue that unspecified, grotesque insects, especially when they boast manlike features, often hint at one of Kafka's most influential stories: The Metamorphosis (1915). Their appearance, in other words, acts under certain circumstances as a Kafka-reference. The first section of my essay discusses gag-cartoons and their affinity with the genre of parody with which they share multiple formal characteristics. Given their reliance on visual cues to tell a story and their limited narrative means, cartoons that draw on Kafka's texts often seek to emulate a visual quality that is easily discernible by readers, which is why the insectoid corporeality of the protagonist in The Metamorphosis, Gregor Samsa, is almost always a point of reference. The second section centers primarily on Charles Burns' graphic novel Black Hole (1995-2005) and his animation Fear(s) of the Dark (2007) in which the imitation of Kafka's style is not as direct as in cartoons but equally evident and effective. The third part examines David Cronenberg's film NakedLunch (1991) and the themes of hybridity that the director deploys in his attempt to create a narrative based on two major sources: William S. Burroughs' novel of the same name, of which the film claims to be an adaptation, and Kafka's The Metamorphosis. The concluding section foregrounds the relationship between an author and her powerful forerunners as well as the struggles of the former to come to terms with the "influence" of the latter.

\section{Defining Cartoons against the Backdrop of Parody}

Imitation, according to Pierre Fontanier, is a figure that "consists of imitating a turn of phrase, a sentence construction, from another language; or a turn of phrase, a sentence construction, that is no longer in use. In the first case, it is called Hellenism, Latinism, Hebraism, Anglicism, etc., depending on whether it comes from the Greek, Latin, Hebrew, or English, etc. ... In the second case, it may be called by the name of the author who provided the model for it. Thus, we give the name Marotism to any affected imitation of Clément Marot's style."

(Genette 1997, pp. 73-74)

By citing Pierre Fontanier's definition of the term imitation, Gerard Genette, in his hugely influential work on transtextual relations Palimpsests (1982), highlights the suffix "-ism" that can be appended to the stem of an author's name in order to express a quality, a mode of writing, a doctrine, or even a movement that springs from her work (Marx-Marxism, Balzac-Balzacism). As opposed to the suffix "-esque", however, the derivation produces not an adjective but a noun. A Marotism or $a$ Balzacism, as Genette states by placing emphasis on the indefinite article, conveys features at play in the work of authors to whose names the suffix "-ism" has been added only then, when those features seek to emigrate, when they appear in texts not written by them but by "imitators" of their style: "Strictly speaking, an Anglicism is identified only as it comes into contact with another language, at the moment it steps out of the English language, and a Marotism when it wanders out of Marot's work" (Genette 1997, p. 76). In this sense, there is nothing Kafkaesque in Kafka's novels and short 
stories because everything in them is Kafkaesque. It is only in relation to other works that one can speak of it and identify it as a distinctive mode of Kafka's style. Kafkaesque is a style, a quality, a situation, a mode or writing etc. when it migrates to texts not written by Kafka himself. The name of an author might well serve as a guardian or rather a doorkeeper, as Foucault argues, yet the distinctive qualities of their oeuvre truly comes to light through an act of trespassing. To put this another way, a Marotism, Balzacism, Kafkaism (another synonym for the Kafkaesque) and similar modes of imitation and appropriation can trick Foucault's border patrol agents and cross the limits that circumscribe an author's textual, visual, or audio-visual domain.

The imitation of the Kafkaesque in gag cartoons, to which I now turn my attention, requires a visual quality of the Adjective because of the narrative constraints of the medium. As opposed to conventional graphic novels and comic strips that are by definition sequential, cartoon-artists have at their disposal a single panel in which they operate with two signifying systems: images and words. Due to that limitation, the presence of hybrid insects is very common in cartoons that allude

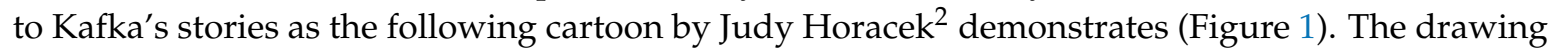
of a bug sitting on a sofa during a psychoanalytic session and the addition of Kafka's name in the speech balloon facilitate the identification of the text on which the cartoon's punch line is based. In some cases, the iconic face of the author is portrayed as well, but even such cases often refer to The Metamorphosis (Figure 3). Illustrators that draw on Kafka's texts and his physical appearance proceed on the assumption that readers are familiar with the hypotext (Kafka's The Metamorphosis) at which they are hinting ${ }^{3}$. In other words, the cartoon itself will fail to deliver its punch line if readers are not acquainted with Kafka's short story, and that forces illustrators to draw on well-known and popular hypotexts.

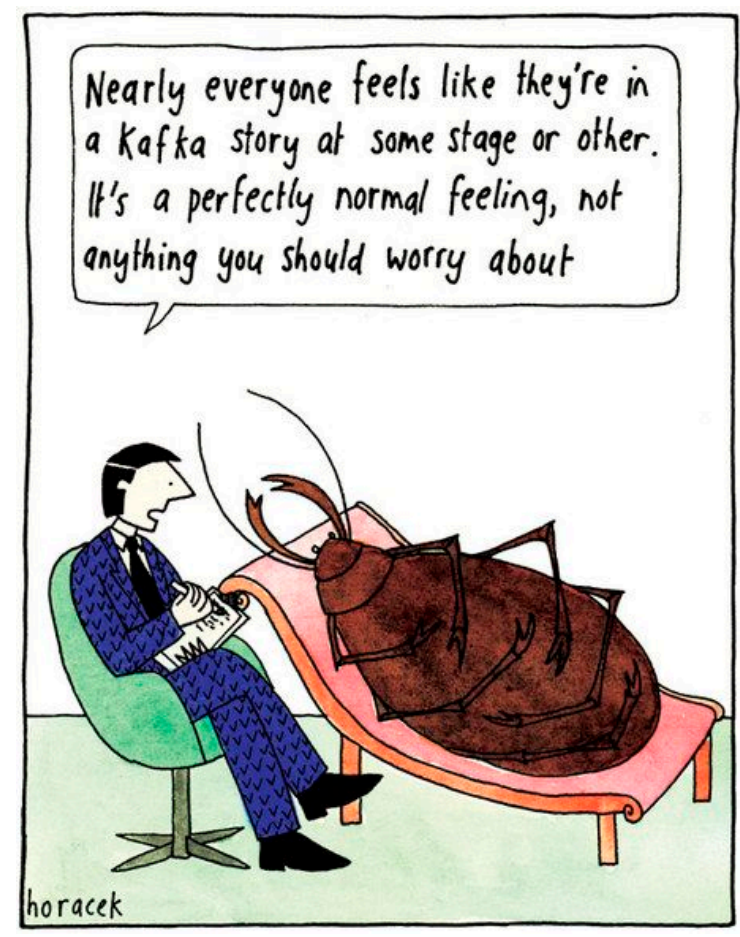

Figure 1. Cartoon by Judy Horacek.

2 I would like to thank Judy Horacek, Pat Bagley, and Jirí Slíva for kindly giving me permission to publish their sophisticated cartoons (Figures 1-3).

3 The term hypotext has been coined by Genette and designates the text upon which the mimetic text, the hypertext (the cartoon in our case), is grafted. 
The cartoons under consideration here have a strong parodic quality given their reliance on a highly influential hypotext, and the genre of parody, as Genette argues, is the mimetic genre par excellence.

The most rigorous form of parody, or minimal parody, consists, then, of taking up a familiar text literally and giving it a new meaning, while playing, if possible and as needed, on the words ... The most elegant parody, since it is the most economical, is then merely a quote deflected from its meaning or simply from its context, or demoted from its dignified status.

(Genette 1997, pp. 16-17)

When a parody draws upon a celebrated text, it does so because the latter is recognizable by a wide audience. By tinkering with single words, phrases, or entire sentences from the parodied work (replacing the letter " $\mathrm{b}$ " with the letter " $\mathrm{p}$ " in the verb "to be" and adding an additional " $\mathrm{e}$ " at the end of the same verb in Shakespeare's famous quote: "to be or not to be" for instance), the writer creates a pun that is funny only due to its reference to the hypotext, and that is the main reason why the parodist has to stay as close to the source text as possible. If readers are not familiar with the referenced work or are unable to recognize the reference, the pun will remain inaccessible to them. While this kind of strictly textual parody is possible in visual media as well, at least in those that employ images and words, it is very rare because a medium that rests on both visual and linguistic cues is at its most effective when both levels are at work. The following political cartoon by Pat Bagley, posted on his Twitter account on 5 March 2016, demonstrates nicely how this type of parody utilizes visual and textual components to generate a pun (Figure 2). The modified first line from Kafka's story, famous in itself, that can be read in the upper left-hand corner of the panel in conjunction with the visual imagery of the panel, which features an insect reading a newspaper, and the current political context, rendered in the form of a headline and an image on the cover of the newspaper, deliver a punch line that hinges on multiples sources to which readers must have access if they are to understand its message. Moreover, the caption of the cartoon ("Kafkaesque") utilizes the prevalent connotations of the Adjective at the vernacular level to emphasize a political development that is more absurd and preposterous in the eyes of the illustrator than the transformation of a human being into a gigantic insect.

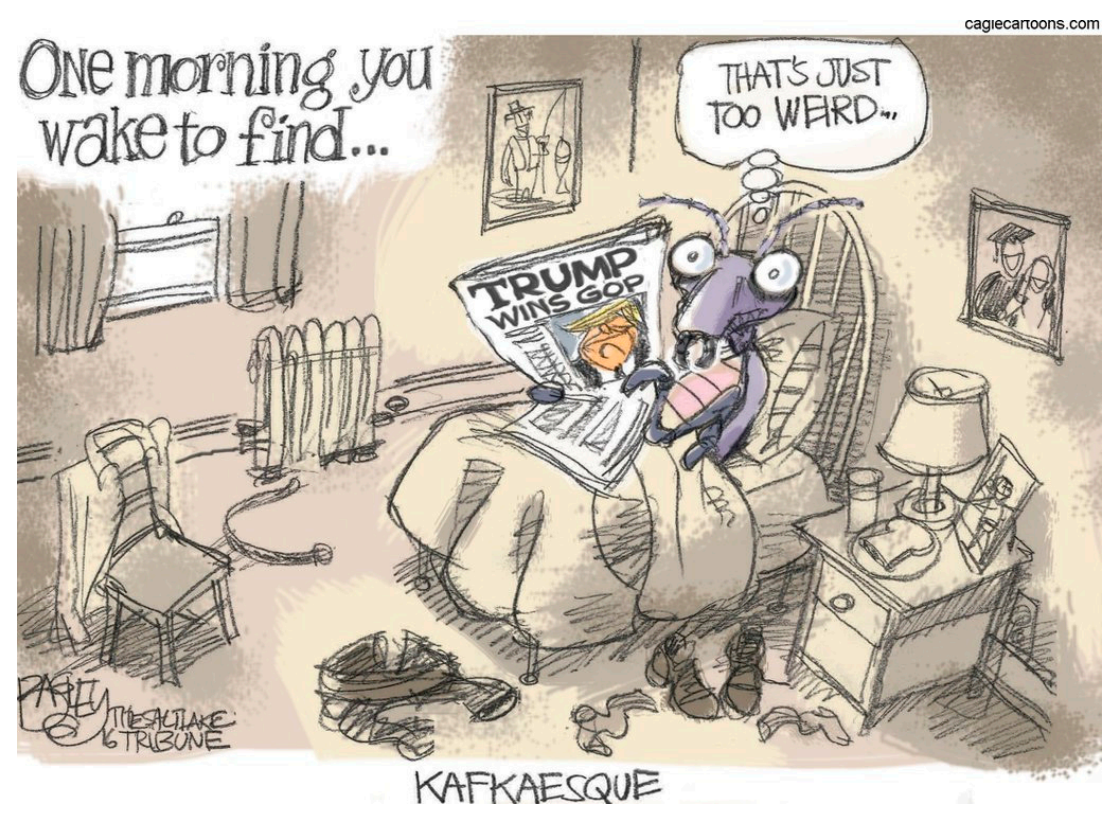

Figure 2. Cartoon by Pat Bagley.

The imitation that lies at the core of cartoons that incorporate elements of Kafka's writings, his name, aspects of his life, and/or his physical appearance, pertain, at least to some extent, to the 
norms of conventional parodies as outlined by Genette. By seeking a proximity to the hypotext and by "diverting the letter of the [source] text to another purpose" (Genette 1997, p. 78) -an operation that creates a comic effect-said cartoons pursue an imitation of the "letter", just like parodies do, but contrary to the latter they also display an imitation that targets the imagery of the hypotext. The emulation of physical appearance, which is to say the medium/genre of caricature, is particularly interesting here because it conforms to the exact same rules that govern the genre of parody. While the parodist imitates a well-known and celebrated text by manipulating its microstructure, the caricaturist sketches the portrait of a famous individual by exaggerating and distorting some of her physical traits and facial characteristics. The artist has to make sure that her audience will recognize her victim despite the rendered distortions, which is why the target of the caricature must be a prominent personality or celebrity. The affinity between caricature and parody becomes axiomatic from this angle. In order to construct an amusing and playful moment, the caricaturist and the parodist draw on a widely recognized hypotext the structure of which they marginally distort, but the effect they hope to achieve hinges upon the ability of readers to discern both the source and its distortion. Hence, the inclusion of a name or other textual hints that facilitate the identification process is not uncommon, especially in caricatures and illustrations like the following by Jirí Sliva entitled Die Verwandlung (The Metamorphosis, Figure 3). Kafka's iconic face in conjunction with the title of the illustration and the notion of hybridity that the unidentified creature evokes create a comic effect that has its roots in the hypotext on which the caricature rests. Furthermore, Slíva's notion of hybridity in this particular illustration might be twofold. Not only is the creature hybrid, half-human, half-hare, but so too are the sources of the caricature; its hypotexts. The first hypotext, Kafka's The Metamorphosis [Die Verwandlung], is clear and indisputable given the many references, but one can only speculate about the other(s). It does seem possible, though, that the illustration refers not only to Kafka's crossbreeds but also to Albrecht Dürer's famous painting Young Hare. As such, it highlights a Kafkaesque mode of hybridity that is active at both the organic (the creature itself) and the referential level (Kafka and Dürer).

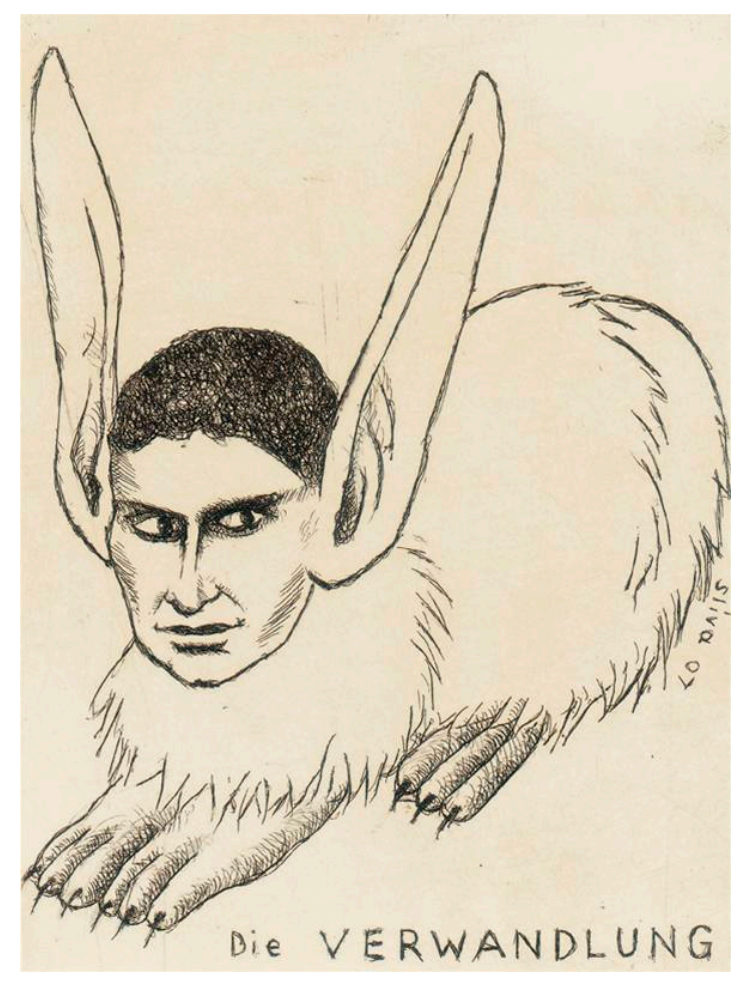

Figure 3. Illustration by Jiri Slíva. 
We must keep in mind that there is, in fact, nothing Kafkaesque in Kafka's texts; that this "mood" can only be identified as such the moment it steps out of the carefully delineated, textual confines of Kafka's oeuvre; when it enters foreign territory; when it occurs in the text of another author or as a visual equivalent in visual or audiovisual media. This assertion raises several concerns, the most important of which is the following: how is imitation of the Kafkaesque possible if we cannot even say what the word signifies? In my study, I do not claim to exhaust the full range of the term but only an aspect of it that I view as a central Kafkan trait: (hybrid) insects. Their appearance in cartoons, films and comic books, as I argue, often alludes to Kafka's The Metamorphosis and particularly to the hapless hero of the story, Gregor Samsa, who awakes one morning to find himself "transformed in his bed into a gigantic insect" (Kafka 1971, p. 89). It comes as no surprise, then, given the formal restrictions of the cartoon-medium that a considerable number of cartoonist often allude to the aforementioned story, particularly to Gregor's corporeality, in their attempts to generate a punch line. The illustration of an insect exhibiting human traits in conjunction with a name or a title serve as a clear reference to Kafka's work that enables readers to identify the source and grasp the gag that springs from it.

\section{Charles Burns' Comic Books and Animations}

"Parasite" is one of those words that calls up its apparent opposite. It has no meaning without that counterpart. There is no parasite without its host.

(Miller 1986, p. 452)

In contrast to cartoons, the presence of elements that evoke Kafka's imagery in comic books is not dependent upon readers' ability to discern the implanted reference, whether the latter is intended or not. According to Genette, whose analysis does not include Kafka's texts, the reoccurrence of certain formulations indicative of an author's style can be used as a platform for imitative practices. When the name of the main protagonist in a fictional narrative, for example, consists of a single letter that happens to be the first initial of the author's name (K. is the name of the lead character in both novels The Castle and The Trial), and when this peculiarity occurs more than just once, one can speak of a distinctive trait and categorize it as a formal feature of the author in question. Themes and motifs that occur repeatedly in an author's oeuvre can be subsumed under the broad category of an author's style as well. From this perspective, hybrid creatures and bodily deformity, to name just those Kafkan topics that are relevant to the present study, represent iterative phenomena in Kafka's texts that appeal to and can be appropriated by imitators. In this sense, what has often been labeled "the author's style" is nothing more than a series of repetitions, and repetitions, as Genette stresses, invite imitations. An imitation, then, occurs when an imitator attempts to simulate iterative formal or thematic features of influential precursors:

What I said once belongs to me and it can be parted from me only by being given over through a voluntary or involuntary transaction, officially acknowledged by a pair of quotations marks. What I have said twice or more ceases to belong to me; it now characterizes me and may be parted from me through a simple transfer of imitation; by repeating myself, I am already imitating myself, and on that point one can imitate me by repeating me.

(Genette 1997, p. 79)

Repetitive elements in the works of influential precursors are often the target of imitators, and a venerable member of that guild of imitators is Charles Burns. In the third chapter of his critically acclaimed and highly unsettling graphic novel Black Hole, an illustration of a slightly disfigured female hand in the third chapter of the comic book directs us towards the character of "Leni" in Kafka's novel The Trial (Leni is the mistress of K.s lawyer and the one who seduces K. in the chapter The Lawyer/Leni). The web of skin that stretches between all fingers of the character's hand in Burns' panel hints at the same passage in Kafka's novel in which a detailed description of Leni's hand is 
presented: "Sie spannte den Mittel- und Ringfinger ihrer rechten Hand auseinander, zwischen denen das Verbindungshäutchen fast bist zum obersten Gelenk der kurzen Finger reichte. [She spread the middle and ring fingers of her right hand apart from each other and between those fingers the flap of skin connecting them reached up almost as far as the top joint of the little finger.]" (Kafka 2002, p. 145). Aside from this very direct intertextual prompt that draws our attention to Kafka's work, the most intriguing references in Burns' works are the ones that hint at The Metamorphosis. In that narrative, the protagonist of the story, Gregor, awakes one morning and finds himself transformed into a grotesque creature, half-human and half-insect. If we adhere to Theodor W. Adorno's principle of literariness ("Das Prinzip der Wörtlichkeit"(Adorno 1963, p. 251)), according to which every single word in Kafka's texts is to be understood literally, and reject symbolical readings of the story that view it as an elaborate metaphor (Corngold 1973, pp. 1-31), then Gregor is indeed a hybrid creature. In his Lectures on Literature (Nabokov 1980), Vladimir Nabokov examines the physiology of Gregor's body based on the evidence at hand in the text and concludes that Gregor must be a beetle. He admits, however, that "the metamorphosis is not quite complete as yet" because a "regular beetle has no eyelids and cannot close its eyes-a beetle with human eyes" (Nabokov 1980, p. 258). Nabokov is referring to the very beginning of the text, shortly after Gregor's realization that he is no longer a human being: "However violently he forced himself toward his right side he always rolled onto his back again. He tried it at least a hundred time, shutting his eyes to keep from seeing his struggling legs ..." (Kafka 1971, p. 89). There is additional evidence scattered throughout the text that confirms Nabokov's observation. Insects, for instance, breathe through their bodies thanks to a network of tubes called tracheae. They have neither noses nor lungs. Gregor, on the other hand, does not conform to this model. The following passage depicts Gregor's last moments before he succumbs to the wound on his back, inflicted by the apple that his father had thrown at him, and the overall neglect that he had to endure from his family: "Then his head sank to the floor of its own accord and from his nostrils came the last faint flicker of his breath" (Kafka 1971, p. 135). Hybridity, as it becomes evident here, is of the essence in The Metamorphosis, and one of the critics who classifies it as a central Kafka motif is Henry Sussman: "Kafka's uncanny architecture, decisive as it was for the twentieth-century imaginaries of literature and the visual arts, incorporates the threshold between the human and the animal, under his administration a particularly active and generative interface" (Sussman 2010, p. 240).

The themes of hybridity and bodily deformity dominate all facets of Burns' oeuvre as well, and the physical appearance of multiple characters allude, to a considerable extent, to Kafka's universe. Not unlike Gregor (The Metamorphosis) and the Kittenlamb (the half-kitten, half-lamb character in $A$ Crossbreed), the two creatures in Kafka's stories that are hybrid by definition, the characters in Burns' Black Hole exhibit a corporeality akin to Kafka's characters. A female body endowed with a tail or a face with feelers, to name just two examples of bodily deformity in Burns' graphic novel, do not directly reference Kafka's texts, but they can be viewed as an imitation of his style. The bizarre creatures that inhabit his latest trilogy, X'ed Out (2010), The Hive (2012), and Sugar Skull (2014), fall under the same broad category of hybrids and creatures as well: unidentified amphibians that speak to and interact with the protagonist of the story, deformed characters with dreadful wounds on their bodies, a slug-like being that boasts a human face, and many other creatures that defy conventional means of classification. The reoccurrence of animals that speak and behave as humans (Red Peter) and inanimate creatures (Odradek) in Kafka's works that defy conventional means of classification can be viewed as an iterative, idiosyncratic feature of Kafka's style that Burns takes on when composing his narratives and designing his characters. The imitation at work here is by no means inferior to the source, for it goes beyond the mere visual reconstruction of a textual, stylistic mode.

The palimpsestuous presence of The Metamorphosis is more directly involved in an equally original and equally disturbing animation by Burns, his only work in this medium to date, that appears as a segment in the French animated anthology Fear(s) of the Dark. The beginning of the story is very similar to that of The Metamorphosis. As Eric, the hero of the story, awakes one morning from uneasy dreams, he finds himself in a bare room that resembles the recovery room of an infirmary. Unable to stand up 
from the bed, his gaze wanders to the only window in the room and the trees outside. At this moment, as the camera slowly zooms into the forest, a flashback sets in, recounting the tragic events that led up to this moment. While wandering through a forest many years ago, the young hero runs across a nest inhabited by insects of an undetermined species. Their unusual human-like appearance (Figure 4) prompts the teenager to capture one of the insects and bring it home to examine it more closely. The specimen eventually is lost and several years later the protagonist moves to a different city to begin his studies at a college. Eric eventually falls in love with a fellow student, Laura, and at some point sleeps with her on the same childhood-bed that he brought along when he moved into his new apartment. During that night, the protagonist realizes that the insect he once thought to be lost was in actuality hiding in a recess of his bed. As the scenes of the animation instruct us to believe, Eric was not the only one who interacted with Laura that night. The parasitic insect drilled its way into Laura's body, leaving a wound behind (Burns' characteristic vagina-looking cut), and from that point on it begins to control her mind. Laura, at the mercy of the parasite and slowly transforming into an insect (Figure 5), begins to dominate and terrorize Eric, forcing him to eat as much as possible. By the end of the story Eric's bloated body is used as a host in which the insects' larvae grow.

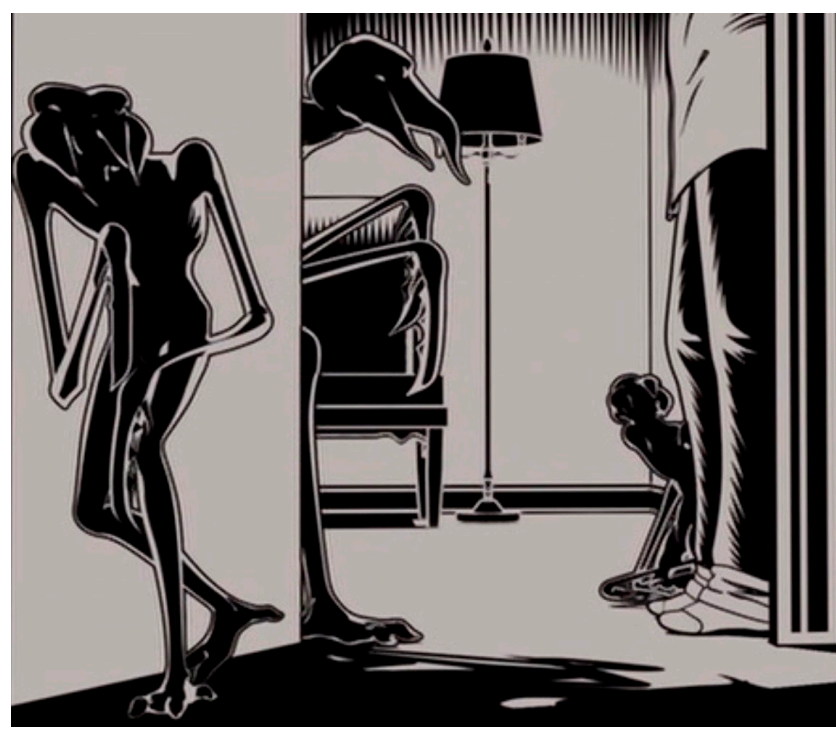

Figure 4. Burns, Charles. Fear(s) of the Dark. Animation. 2007.

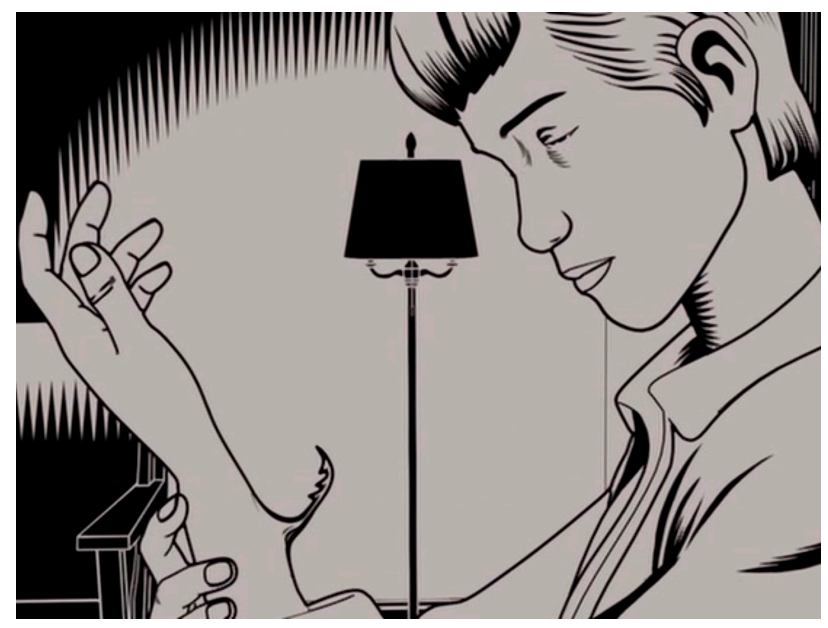

Figure 5. Burns, Charles. Fear(s) of the Dark. Animation. 2007. 
The animation bears a striking resemblance to Kafka's short story and the relationship between his work and the text upon which it is transplanted can be read as the outcome of a complex type of misreading that Harold Blooms terms "poetic misprision". Poetic misprision, according to Bloom, concerns the relation of an author to a celebrated forerunner and the efforts of the former to repudiate the power that the latter exerts over him or her. By misreading the precursor, the "ephebe", as Harold Bloom labels imitators of great poets (Bloom 1997, p. 10), attempts to overcome his or her influence and clear space for herself. This "anxiety of influence" is a considerable creative force that has given rise to works of unparalleled depth and scope, but in those works the voice of the forerunner, well hidden in the depths of the newly crafted work, is always active. Like a parasite turning a human body into its new domicile, the precursor comes to life through the agony and creative force of the ephebe, despite the efforts of the latter to deny the existence of the former or rather because of them. "[S]trong poems are always omens of resurrection. The dead may or may not return, but their voice comes alive, paradoxically never by mere imitation, but in the agonistic misprision performed upon powerful forerunners by only the most gifted of their successors" (Bloom 1997, p. xxiv). Whether the works of Burns' discussed here are the outcome of poetic misprision or not is open to debate. What is certain, though, is that the ground upon which his narratives grow is covered by Kafka's texts. In this sense, Kafka's "body of work" is akin to Eric's body. They both serve as a maternal womb out of which insects and insect-narratives ceaselessly hatch. Yet Kafka is by no means the only powerful precursor active in Burns' animation ${ }^{4}$. Every major work of art harbors more than just one "parasite" and the manner in which they inform and impact their "host" is considerable.

A central motif in both Kafka's The Metamorphosis and Burns' segment of Fear(s) in the Dark is "parasitism". Yet before I turn my attention to those works, it should be noted that the word "parasite" has two meanings in English: a biological and a social. In its social application, as a metaphor, a parasite designates a person who exploits the generosity of his or her benefactor without giving anything in return. The biological meaning of the word, on the other hand, refers to an organism that lives on or in another organism, feeding on it, and contributing nothing to its health and survival (Miller 1986, p. 453). In The Metamorphosis, the social meaning of the word "parasite", not the biological, is dominant. His transformation robs Gregor Samsa of the ability to interact with other people, and he soon realizes that his survival hinges upon the benevolence of his parents and his sister. Unable to offer anything in return, he finds himself in a state of absolute dependence. He has, in other words, not only been transformed into an insect but also into a parasite, at least in a social sense. The parents themselves, however, were parasitical on him before his transformation (Gregor was the sole provider of the entire family), and from that angle the metamorphosis marks an inversion in that relationship, turning the parasite into a host and vice versa. The parasite-metaphor in Kafka's Letter to his Father (1919) resonates with this notion too, although the German word that the author employs in that text is "Schmarotzer": a synonym of "parasite" ("Parasit" in German) that is more common in social contexts 5 . Bearing those references in mind, The Metamorphosis story appears to be a fictional version of Kafka's relationship to his father, and it should not come as too much of a surprise that many critics interpret The Metamorphosis as an elaborate metaphor. It is hard to tell, though, who is the parasite of who the host in both the real and the fictional version of that relationship.

4 William S. Burroughs' novels, Lynd Ward's woodcut novels, and David Cronenberg's films, to name just those hypotexts that are known to me, are all at work in Burns' oeuvre.

5 Towards the end of Letter to His Father, Kafka speculates how his father would respond to his long letter and sets out to write down that response on behalf of his father. The following passage from the text is written from the imaginary point of view of Kafka's father: “Im Grunde aber hast Du hier und in allem anderen für mich nichts anderes bewiesen, als daß alle meine Vorwürfe berechtigt waren und daß unter ihnen noch ein besonders berechtigter Vorwurf gefehlt hat, nämlich der Vorwurf der Unaufrichtigkeit, der Liebedienerei, des Schmarotzertums. Wenn ich nicht sehr irre, schmarotzest Du an mir auch noch mit diesem Brief als solchem" [Basically, however, in this as in everything else you have only proved to me that all my reproaches have been justified, and that one reproach in particular was still missing, namely the charge of insincerity, fawning, and parasitism. If I am not very mistaken, you are parasitical on me even with this letter] (Kafka 1995, p. 58). 
In Burns' animation, the relationship between parasite and host is more straightforward given the biological implications. Apart from the references to Kafka's stories, the work clearly alludes to several parasitic species that use their host's body as a habitat and even engage in mind control. The behavior of the parasitic barnacle sacculina, for instance, is reminiscent of the insects that have parasitized Eric's body. The female sacculina larva colonizes a crab by plunging its way into the crab's exoskeleton through a soft chink on the arm. The crab's immune systems cannot fight off the intruder, and the parasite slowly grows inside the crab. Once a male sacculina larva joins the host, it endlessly fertilizes the female's eggs, and together they produce thousands of Sacculina larvae every few weeks. In Parasite Rex (Zimmer 2000), Carl Zimmer describes in detail how the parasite affects the crab's physiology and behavior: "The crab begins to change into a new sort of creature, one that exists to serve the parasite... And while other crabs mate and produce a new generation, parasitized crabs simply go on eating and eating. They have been spayed. The parasite is responsible for all these changes" (Zimmer 2000, p. 81). Following up on that observation, Zimmer goes on to remark: "But parasites such as Sacculina do more: they control their hosts, becoming in effect their new brain, and turning them into new creatures. It is as if the host itself is simply a puppet, and the parasite is the hand inside" (Zimmer 2000, p. 82). In Burns' animation, the insectoid parasites have turned Eric's body into their new home, but they have not taken over his mind. They do, however, control the mind of his girlfriend, Laura, who is apparently changing into an insect herself (Figure 5). Similar to the cabbage worm caterpillar that a species of parasitic wasp turns into a bodyguard (Zimmer 2000, p. 84), Laura assumes her new role as a guardian, protecting the insects' larvae and making sure that Eric gets all the "care" that he needs. The themes of mind control, bodily deformity, hybridity, and animalistic impulses that reverberate throughout the animation hint at another powerful precursor at work here on whose works Burns draws: the auteur David Cronenberg. His film Shivers (1975) takes advantage of the deep-seated human fear of parasites, presenting phallic creatures that drastically increase the sexual desire of their human hosts. The film, however, that can be read in relation not only to Burns' but also to Kafka's texts is Cronenberg's Naked Lunch.

\section{4. "Exterminate all rational thought": David Cronenberg's Naked Lunch}

It's like an agent. An agent who's come to believe his own cover story. But who's in there, hiding in a larval state ... just waiting for the proper time to hatch out.

(NakedLunch 1991)

Taking into consideration the vast discrepancies between David Cronenberg's film Naked Lunch and William S. Burroughs' novel of the same name on which the film is based, one can hardly speak of a conventional adaptation. The director takes the liberty to utilize facts from Burroughs' life and fuses them with the distinct trademarks of his own films, including transformation (The Fly) and hybridity (eXistenZ, Videodrome) among many others. The main story line centers on William (Bill) Lee, an alter ego of Burroughs played by Peter Weller, his struggles with drugs, the hallucinations that they induce, and his efforts to complete the book that will establish him as one of the most intriguing writers of the twentieth century: Naked Lunch. The first few scenes of the film, aside from establishing the mood, setting, and philosophy of the work, contain a treatise on the theme of re-writing presented in the form of a dialogue between Bill, Hank (the alter ego of Jack Kerouac played by Nicholas Campbell), and Martin (the alter ego of Alan Ginsberg played by Michael Zelniker). The dialogue will be quoted in full because of its great importance:

Hank: So you can't rewrite, 'cause to rewrite is to deceive and lie, and you betray your own thoughts. To rethink the flow, and the rhythm and the tumbling out of the words ... is a betrayal. It's a sin, Martin. It's a sin.

Martin: I don't accept your Catholic interpretation of my compulsive necessity to rewrite every single word at least a hundred times. Guilt is ... Guilt is the key, not sin. Guilt re not 
writing the best that I can. Guilt re not considering everything from every possible angle. Balancing everything.

Hank: Well, how about guilt re censoring your best thoughts? Your most honest, primitive, real thoughts. Because that's what your laborious rewriting amounts to, Martin.

Martin: Is rewriting really censorship, Bill? Because I'm completely fucked if it is.

Bill: Exterminate all rational thought. That is the conclusion I have come to. (NakedLunch 1991)

The dialogue conveys the writing philosophy of Kerouac and Ginsberg, referring particularly to Kerouac's Essentials of Spontaneous Prose (1958) and the improvisational fluidity of his works (his most famous novel On The Road was written in just three weeks). Burroughs' "cut-up technique", which is a type of montage that Burroughs used to rearrange his texts by cutting them up and creating new units out of them-a technique that undermines any attempt to extract a stable meaning from them-is at play here as well. Beyond those references, the above-cited dialogue reads as a sophisticated metatextual elaboration of re-writing procedures. Hank's position touches upon the traditional dichotomy between speech and writing, what Derrida names "logocentrism", according to which writing is subordinate to speech because speech, so goes this line of thinking, produces writing and not the other way around ${ }^{6}$. Hank (that is Kerouac) thus seeks to establish a mode of writing that is as close to his thought as is speech. In addition, his reluctance to rewrite i.e., refine the already written entails a refusal to delve into a palimpsestuous activity by imitating, for example, an author's style.

The repeated re-occurrence of the word "re" as both a prefix and a preposition in the dialogue is relevant here as well. As a preposition, and according to the online Oxford Living Dictionaries, "re" signifies "in the matter of" and/or "about; concerning" (Online Oxford Living Dictionaries 2017a) and as a prefix, among other things: "1. once more; afresh; anew, 1.1 With return to a previous state" (Online Oxford Living Dictionaries 2017b). "Re", in other words, signals a backward movement, a circling-back-to something, a re-turn to something previously established with the intention of either

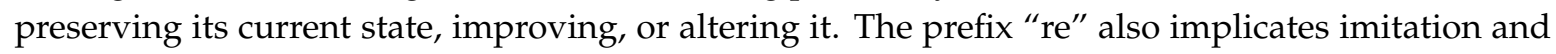
forgery; a proliferation, re-appearance, and repetition of something original by means of re-production, which helps explain Hank's unwillingness to indulge in similar endeavors. Seeking to access the spontaneity and purity of his thoughts in order to create a work of sheer originality, Hank condemns re-writing as a sin. Ginsberg's alter ego (Martin), on the other hand, desires a perfectly balanced form that can only be achieved, as he argues, through an act of "compulsive" rewriting. By constantly going back to his own writings, by ceaselessly polishing their shape and balancing their rhythm, he hopes to produce a form as close to perfection as possible. The backward motion that Martin foregrounds here is crucial, for re-writing i.e., imitating are marked by the same impulses: going back to the source and re-writing it so as to (allegedly) improve it. Bill's, that is Burroughs' (or is it Cronenberg's?) answer to this "anxiety of influence" is very simple and direct: "Exterminate all rational thought". Said definition perfectly captures the film's "logic", which strategically defies logic, and can be applied to Kafka's texts as well given the notions of absurdity that both works have in common.

The first scene of the film establishes Bill's profession and sets the plot in motion. Bill is a bug-exterminator who runs out of bug-powder in the middle of a job. Being unable to explain the shortage of bug-powder to his employer and puzzled by the incident, he meets his friends Hank and Martin at a dinner and tells them about the incident (the dialogue cited above has been taken from the same scene). Hank hints that the missing powder might be a "domestic problem", indicating that Bill's wife, Joan, could be involved in its disappearance. In the following scene, Bill enters his apartment and finds his wife injecting bug-powder into her breast. Joan ${ }^{7}$, slightly shaken by the bug-drug she just injected into her body, explains to Bill what makes bug-powder so special:

6 Derrida goes on to take that notion apart in his Of Grammatology (1967).

7 Joan was the name of Burroughs' real wife whom he accidently shot during a William Tell game. 
Joan: It's ... It's a very literary high. Very literary.

Bill: What do you mean it's a literary high?

Joan: It's a Kafka high. You feel like a bug. Try some.

Bill: Well, I don't know. I don't know. I think our metabolisms are very different.

Joan: Whose? Yours and Kafka's? (NakedLunch 1991)

Bill, intrigued by his wife's statement, injects the Kafka-powder into his veins so as to experience himself what a literary high really feels like. The drug induces a series of hallucinations that manifest themselves in the following scenes in a series of hybrid, insectoid creatures, revealing to the spectator what a Kafka-high feels like or rather what it looks like (Figures 6 and 7). A Kafka-high (another intriguing synonym/neologism of the Kafkaesque?) signifies not as much feeling like a bug but rather seeing hybrid bugs on the screen. The events that follow after the injection of the Kafka-drug set the driving philosophy of the film ("exterminate all rational thought") in motion, and Bill proceeds to exterminate reason with the same passion that he used to exterminate bugs. The moment Bill consumes the bug-powder is also the moment that the film injects a powerful amount of Kafka-drug into its own veins. Hybrid insects and insectoid devices take over, transforming the film into a monstrous, Frankensteinian artwork. Kafka's texts, especially his Metamorphosis, and Burroughs' life and writings, the two major hypotexts of the film, reveal themselves and merge with Cronenberg's vision of insectuous re-writing.

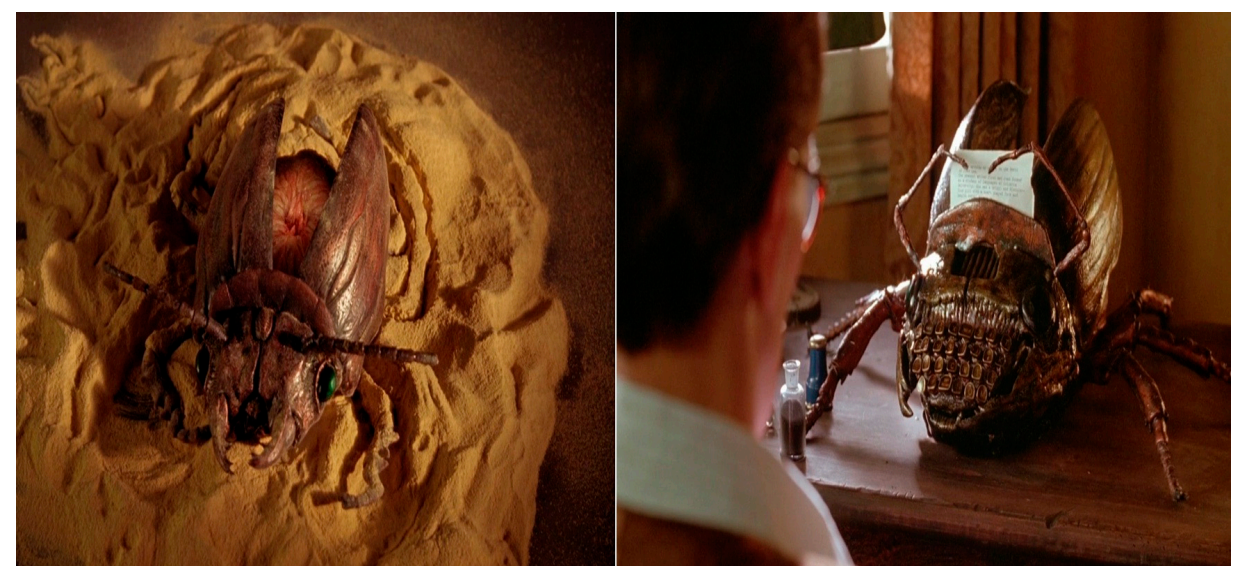

Figure 6. Cronenberg, David. Naked Lunch. Film. 1991.

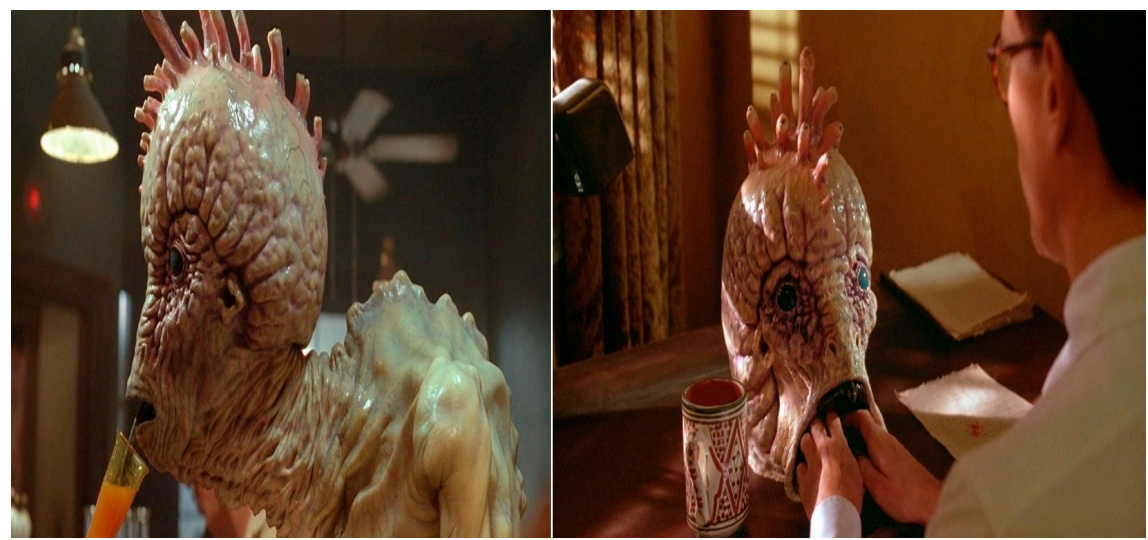

Figure 7. Cronenberg, David. Naked Lunch. Film. 1991. 
If we take the metaphor of the bug-powder as a highly addictive Kafka-drug a step further, we can conclude that Kafka's writings in general and The Metamorphosis in particular have caused a serious addiction in our culture. It is an epidemic that has spread through a wide array of visual and audiovisual media in which hybrid insects ceaselessly multiply. And the infestation cannot be contained. The field of literary studies has not been spared either. As critics and Kafka aficionados, we all need our daily Kafka-dose to get through the day. The Kafka-drug runs through our veins, but it is also inscribed on the DNA of readers that have not yet had the pleasure of reading any of Kafka's texts, for the Kafka-substance can be obtained in a variety of media today in which His presence and influence is omniscient.

\section{On Fathers and Forefathers}

Shakespeare did not think one thought and one thought only; rather scandalously, he thought all thoughts, for all of us ... The issue is not belief but our human nature, so intensified by Shakespeare as to be his re-invention. How can we historicize Shakespeare if we are children of Shakespeare, mapping our origins and our horizons in his diction, in his astonishing vocabulary of some 22,000 separate words?

(Bloom 1997, pp. xxvii-xxviii)

Harold Bloom's The Anxiety of Influence (1973) can be read as a reaction to Barthes' hugely influential essay The Death of the Author (1967), in which the latter proclaims the end of the author's tyranny over literary criticism. In his essay, Barthes exterminates the author-instance with the agency of a performative utterance, by simply proclaiming the author's death in the title of his essay. While John L. Austin's work How to Do Things with Words (1962), to which Barthes alludes in his text, is focused on speech and speech acts Barthes addresses the performative properties of writing when he notes that it "designates exactly what linguists ... call a performative, a rare verbal form ... in which the enunciation has no other content (contains no other proposition) than the act by which it is uttered-something like the I declare of kings or the I sing of very ancient poets" (Barthes 1977, pp. 145-46). Barthes does not directly declare the death of the author ("I sentence you to death" would be a typical performative sentence), but his essay can be viewed as a written declaration that does perform an action inasmuch as it changes a given social reality. By applying the performative properties of writing, in other words, Barthes brings an end to the reign of the author and raises the status of the reader by simply announcing the death of the former and the birth of the latter: the author is dead. Long live the reader. It is important to note here that the new established rule of the reader is also the rule of the critic who is a reader herself. Bloom's anxiety on the other hand strives to resurrect the author and restore His authority by regarding Shakespeare as the personification of the Author-God whom Barthes sought to cast out. By utilizing the same performative properties of writing as Barthes, Bloom declares Shakespeare the ultimate Origin and his texts as having no other source other than themselves. "Shakespeare has influenced the world far more than it initially influenced Shakespeare" (Bloom 1997, p. xvi). In this sense, Shakespeare's texts gain the same status as the Bible or any other religious text. They originate from a source beyond our grasp. Shakespeare, as Bloom writes, "invented us, and continues to contain us" (Bloom 1997, p. xvi), which amounts to: the (short) reign of the reader is over. Long live Shakespeare.

A response to Barthes' essay came from Michel Foucault too who, as we already saw, was more concerned with the function of the author's name. His equally influential essay What Is an Author? (1969) and the arguments that he lays out in it are less performative in nature and purport to be more substantial and practical than the ones put forth by Barthes. Foucault does not attempt to resurrect the author as Bloom does, but he does raise the status of selected authors above the rest when he introduces the term "initiators of discursive practices". An initiator of said practices is an author who produces not only their own work, as Foucault asserts, "but the possibility and the rules of formation of other texts. In this sense, their role differs entirely from that of a novelist, for example, who is 
basically never more than the author of his own text" (Foucault 1980, p. 131). The authors Foucault designates as initiators are Freud and Marx and he goes to great lengths to substantiate his claim that literary authors are excluded from this equation (Foucault 1980, pp. 132-33). In his analysis, only theorists and critics can become initiators of discursive practices, not authors of fiction or the founders of a science, a point that aligns him with Barthes who refers to the rise of the critic when he announces the birth of the reader at the cost of the author. And let us not forget that Foucault, the founder of discourse analysis, can be considered an initiator himself. Foucault's essay can also be seen as a partial influence study. This reality becomes evident when he stresses the importance of the "origin" and the necessity to go back to the source: "it is inevitable that practitioners of such discourses must 'return to the origin'" (Foucault 1980, p. 134). Towards the end of his essay, he follows up on his previous thought with the following statement: "These returns, an important component of discursive practices, form a relationship between 'fundamental' and mediate authors, which is not identical to that which links an ordinary text to its mediate author" (Foucault 1980, p. 136). The returns Foucault is referring to presuppose a re-writing of the source, at least in terms of imitation. In order to remain within the contours of a recently established discourse, a "practitioner", imitator, or descendant has to follow the rules and norms established by the initiator and that can only be achieved through an act of imitation: by going back to the source and re-writing it.

According to Monika Schmitz-Emans, the significance of an author's work is not limited to the influence that $\mathrm{s} /$ he has on subsequent generations of writers but should also be measured against the backdrop of works that have influenced the author in question as well (Schmitz-Emans 2008, p. 273), and the list of writers that have impacted Kafka's texts, as Emans demonstrates, is very long. This notion is refuted by Bloom, however, at least when it comes to Shakespeare who did far more than just that: "Shakespeare is the largest instance in the language of a phenomenon that stands outside the concern of this book: the absolute absorption of the precursor" (Bloom 1997, p. 11). While Bloom categorically dismisses any connection between his and Freud's theory and refuses to see his study in terms of an oedipal conflict, his remarks on Shakespeare suggest otherwise. Shakespeare commits parricide in Blooms account, killing his forefather, Christopher Marlow, and consuming him, not unlike the sons of the primal horde to whom Freud refers to in Totem and Taboo (1913). The father/king of the ancient primal horde, as Freud argues in his book, kept all women of the tribe for himself and oppressed his sons. Then, one day, his sons forged an alliance, plotted against him, and eventually killed him. Shortly thereafter, they consumed the corpse of their father in order to appropriate his powers (an interesting although somehow morbid case of re-writing). After the dreadful act, however, they soon realized that their feelings towards their now deceased father were more ambivalent than they originally thought. The sons hated their father, but they also loved and admired him, and those feelings gave rise to a powerful sensation of remorse: "Es geschah in der Form der Reue, es entstand ein Schuldbewußtsein, welches hier mit der gemeinsam empfundenen Reue zusammenfällt. Der Tote wurde nun stärker, als der Lebende gewesen war; [It took the form of remorse; a guilty conscience came about that coincided with the overall felt remorse. The dead now became stronger than the living had been;]" (Freud 1974, p. 427). The dead father becomes more powerful now than he ever was during his lifetime, and this unspecified moment in the timeline of human history, as Freud "declares", marks the birth of human "Schuldbewußtsein" (guilty conscience).

The cannibalistic relationship between father and son(s) in Freud's account is not very different from Bloom's concept of "poetic misprision" 8 (to say nothing of the Christian rite of the Eucharist). In an act of cannibalistic re-reading and re-writing, the ephebe devours/rewrites the hated but also admired great forerunner so as to appropriate his prowess and take his place. The consumption of the

8 In contrast to the sons of the primal horde that Freud mentions in his narrative, and barring a "case of indigestion that Marlowe caused the Moby-Dick of all playwrights" (Bloom 1997, p. xxi), Shakespeare did not develop any guilty conscience after devouring Marlowe. In Blooms account, Shakespeare is the conscience of all son-authors who, eagerly and ceaselessly, feed on his body. 
forefather, however, comes at price: the authority of the father-author, already overwhelming before the attempt at imitation, becomes all-encompassing now. The son-writer ceases to be the "master in its own house", ${ }^{9}$ to use a Freudian catchphrase, given the dominant influence that the dead forefather now exerts on him. The parricide creates a parasite. By consuming the "body of work" of a major poet, the ephebe becomes "infected" by the precursor's ideas, thoughts, motifs, and techniques, and contributes, unwillingly, to their dissemination.

In her essay "The Medium is the Message: Cronenberg 'Out-Kafkas' Kafka”, Iris Bruce makes two central observations. Firstly, she establishes a connection between Cronenberg's and Kafka's narratives by highlighting the motif of the "open wound" in Kafka's short story A Country Doctor (Ein Landarzt, 1917) and relating it to the open wounds that many Cronenbergian characters have on their bodies. The same motif is also the visual trademark of Burns' oeuvre, especially in Fear(s) of the Dark and Black Hole in which it often appears in the form of a cut of the skin that resembles a vagina. Bruce's second observation concerns the physiology of the oversized beetle in Naked Lunch and its hybrid version, a creature half-beetle, half-typewriter, with which the protagonist communicates. The creature, as Bruce notes, "speaks through a hole in his back, which in 'The Metamorphosis' was caused by the wound created by the apple which his father threw at Gregor. Here, however, Cronenberg has transformed Gregor's wound into a Burroughesque anus: the bug talks through his asshole" (Bruce 2016, p. 226). Bruce goes so far as to claim that Gregor actually appears "in flesh" in the scenes that feature the anus-beetle. Regardless if one agrees with that claim or not, the beetle-hybrid acts as an intertextual cursor in the film, pointing unmistakably to The Metamorphosis.

Given the multiple direct and indirect references to Kafka and the fact that the film claims to be an adaptation of Burroughs' most celebrated novel, the work can be viewed in terms of the relation that writers entertain with their precursors. Bill's first encounter with the typewriter-beetle (Figure 6) is particularly intriguing in this respect. At some point during the scene, the Kafkaesque Gregor-beetle asks Bill for a "favor" and prompts him to write something down: "I want you to type a few words into me. Words that I'll dictate to you." Bill reluctantly agrees and sets out to write the sentence that the creature "dictates" (an interesting synonym of "influence") to him by using the beetle's keyboard. In a scene that calls to mind the cruel execution-device of Kafka's Penal Colony (In the Penal Colony, 1918), the protagonist literally types into the Gregor-beetle. His writing is filtered through the Gregor-typewriter and emerges from it. The Burroughsesque mugwump-typewriter (Figure 7) that secretes hallucinogenic substances when Bill composes his "reports" can be interpreted along similar lines ${ }^{10}$. Bearing in mind the fact that the protagonist of the film is actually writing a novel, if only unconsciously, the above scenes illustrate nicely the hypotextual ground upon which every important work of art grows.

As the analysis of the selected cartoons, graphic novels, and films has demonstrated, the visual presentation of unspecified (grotesque, oversized, hybrid) insects in visual narratives is a genuine Kafkaesque trait. Their proliferation in said media is proof of the continuous influence that Kafka's texts in general and The Metamorphosis in particular exert on contemporary illustrators and filmmakers to whose works this study was limited. Kafka and Ovid are after all the writers, as Monika Schmitz-Emans states, that have profoundly shaped the metamorphosis-trope (Schmitz-Emans 2008, p. 289). For Joan, moreover, the female character in Naked Lunch, "Kafka-high" means as much as feeling "like a bug". In her view, bugs operate as symbols that point to a representative work of Kafka's texts, The Metamorphosis, and as a consequence to Kafka himself. Bugs are Kafkaesque. As to the relationship

9 "But the third and most irritating insult is flung at the human mania of greatness by present-day psychological research, which wants to prove to the "I" that it is not even master in its own home, but is dependent upon the most scanty information concerning all that goes on unconsciously in its psychic life." (Freud 1920, p. 247).

10 The mugwump creature refers directly to Burroughs' source text Naked Lunch (1959): "Mugwumps have no liver and nourish themselves exclusively on sweets. Thin, purple-blue lips cover a razor-sharp beak of black bone with which they frequently tear each other to shreds in fights over clients. These creatures secrete an addicting fluid from their erect penises which prolongs life by slowing metabolism" (Burroughs 2001, p. 46). 
between artists and their precursors, their "bodies" are both parasite and host at the same time. As J. Hillis Miller argues in his seminal essay The Critic as Host (1976): "The new poem both needs the old texts and must destroy them. It is both parasitical on them, feeding ungraciously on their substance, and at the same time it is the sinister host which unmans them by inviting them into its home" (Miller 1986, p. 456). What Miller notes with regard to new poems pertains to Kafka's body as well: his oeuvre is both the host that nurtures insectoid narratives but also the parasite that sneaks into an artist the moment the latter consumes his intoxicated texts.

A crucial point is still missing, though. From a biological point of view, a parasite has to make one last effort in order to come full circle, as Zimmer writes: "No matter how comfortable a parasite may make itself by altering its host, it has to leave sooner or later" (Zimmer 2000, p. 83). In works of art, that moment occurs when the precursor's ideas and motifs emerge, in disguised form, on the pages or the screen of the ephebe's work. In that work, however, the ephebe and precursor(s)'s thoughts coalesce, creating a hybrid artwork with multiple origins. With some luck, said artwork will find its way into a broad audience which will enable it to act as a parasite (precursor) itself in the perpetual inversion of parasite and host.

Conflicts of Interest: The author declares no conflict of interest.

\section{References}

Adorno, Theodor W. 1963. Aufzeichnungen zu Kafka. In Prismen. Kulturkritik und Gesellschaft. München: Deutscher Taschenbuch Verlag.

Anz, Thomas. 1992. Franz Kafka. München: Verlag C.H. Beck.

Barthes, Roland. 1977. The Death of the Author. In Image, Music, Text. New York: Hill and Wang.

Biderman, Shai. 2016. K., the Tramp, and the Cinematic Vision: The Kafkaesque Chaplin. In Mediamorphosis: Kafka and the Moving Image. Edited by Shai Biderman and Ido Lewit. London and New York: Wallflower Press.

Bloom, Harold. 1997. The Anxiety of Influence: A Theory of Poetry. New York and Oxford: Oxford University Press.

Brady, Martin, and Helen Hughes. 2016. 'The Essential is Sufficient': The Kafka Adaptations of Orson Welles, Straub-Huillet and Michael Haneke. In Mediamorphosis: Kafka and the Moving Image. Edited by Shai Biderman and Ido Lewit. London and New York: Wallflower Press.

Bruce, Iris. 2016. 'The Medium is the Message': Cronenberg 'Outkafkas' Kafka. In Mediamorphosis: Kafka and the Moving Image. Edited by Shai Biderman and Ido Lewit. London and New York: Wallflower Press.

Burroughs, William S. 2001. Naked Lunch. Edited by James Grauerholz and Barry Miles. New York: Grove Press.

Corngold, Stanley. 1973. The Commentators' Despair: The Interpretation of Kafka's Metamorphosis. Port Washington and London: Kennikat Press.

Crumb, Robert, and David Zane Mairowitz. 2010. Kafka. Seattle: Fantagraphic Books.

Foucault, Michel. 1980. What Is an Author? In Language, Counter-Memory, Practice. Selected Essays and Interviews by Michel Foucault. Edited by Donald F. Bouchard. Ithaca: Cornell University Press.

Freud, Sigmund. 1920. A General Introduction to Psychoanalysis. New York: Boni and Liveright.

Freud, Sigmund. 1974. Totem und Tabu: Einige Übereinstimmungen im Seelenleben der ilden und der Neurotiker. In Fragen der Gesellschaft: Ursprünge der Religion. Frankfurt am Main: Studienausgabe; S. Fischer Verlag, vol. IX.

Genette, Gérard. 1997. Palimpsests: Literature in the Second Degree. Lincoln and London: University of Nebraska Press.

Kafka, Franz. 1971. The Metamorphosis. In Franz Kafka: The Complete Stories. Edited by Nahum N. Glatzer. New York: Schocken Books.

Kafka, Franz. 1995. Brief an den Vater. Edited by Michael Müller. Stuttgart: Philipp Reclam jun.

Kafka, Franz. 2002. Der Prozeß. Frankfurt am Main: Kritische Ausgabe, Fischer Taschenbuch Verlag.

Karl, Frederick R. 1991. Representative Man. New York: Ticknor \& Fields.

Miller, J. Hillis. 1986. The Critic as Host. In Critical Theory since 1965. Edited by Hazard Adams and Leroy Searle. Tallahassee: Florida State University Press.

Nabokov, Vladimir. 1980. Lectures on Literature. Edited by Fredson Bowers. London: Weidenfeld and Nicolson. 
Nägele, Rainer. 2006. Kafkaesk. In Odradeks Lachen: Fremdheit bei Kafka. Edited by Gerhard Neumann and Günter Schnitzler. Freiburg i. Br and Berlin: Rombach Verlag.

Naked Lunch. Directed by David Cronenberg. London: Recorded Picture Company (RPC), 1991.

Online Merriam-Webster. 2017a. Dictionary, s.v. "-esque”. Available online: https:/ /www.merriam-webster.com/ dictionary/-esque (accessed on 23 August 2017).

Online Merriam-Webster. 2017b. Dictionary, s.v. “Kafkaesque”. Available online: https:/ /www.merriam-webster. com/dictionary/Kafkaesque (accessed on 23 August 2017).

Online Oxford Living Dictionaries. 2017a. s.v. "re" (as a preposition). Available online: https://en. oxforddictionaries.com/definition/re (accessed on 23 August 2017).

Online Oxford Living Dictionaries. 2017b. s.v. "re-" (as a prefix). Available online: https:/ / en.oxforddictionaries. com/definition/re- (accessed on 23 August 2017).

Schmitz-Emans, Monika. 2008. Kafka und die Weltliteratur. In Kafka-Handbuch: Leben-Werk—Wirkung. Edited by Bettina von Jagow and Oliver Jahraus. Göttingen: Vandenhoeck \& Ruprech.

Searle, John R. 1970. Proper Names. In Mind. New Series, No. 266; Cambridge: Cambridge University Press, vol. 67, First published 1958.

Sussman, Henry. 2010. Extraterrestrial Kafka: Ahead of the Graphic Novel. In Kafka's Creatures: Animals, Hybrids, and Other Fantastic Beings. Edited by Marc Lucht and Donna Yarri. Lanham, Boulder, New York, Toronto and Plymouth: Lexington Books.

Todorov, Tzvetan. 1973. The Fantastic: A Structural Approach to a Literary Genre. Cleveland and London: The Press of Case Western Reserve University.

Zimmer, Carl. 2000. Parasite Rex: Inside the Bizarre World of Nature's Most Dangerous Creatures. New York: The Free Press.

Žižek, Slavoj. 2008. In Defense of Lost Causes. London and New York: Verso.

(C) 2017 by the author. Licensee MDPI, Basel, Switzerland. This article is an open access article distributed under the terms and conditions of the Creative Commons Attribution (CC BY) license (http:/ / creativecommons.org/licenses/by/4.0/). 